\title{
Achieving the Performance Excellence through Quality Culture Improvement Strategy in Hospitality Industry
}

\author{
Mohamed Mahmoud Ahmed Eissa \\ The Higher Institute for Hotel and Tourism Management \\ Hurghada - Hotel Studies Department
}

\begin{abstract}
This study aims to develop a quality improvement model for hotels. This model is assumed to be fast, simple, and effective for hospitality organizations because it includes the proven critical success factors of Kanji's excellence model. "(KBEM) is a business excellence model that originated from principles of total quality management". Total Quality Management (TQM) is a management philosophy that seeks to integrate all organizational functions to focus on meeting customer needs and organizational quality objectives. TQM is one of the most applied and well accepted approaches between the contemporary innovations such as; six sigma, just-in- time to achieve business excellence. In the last two decades a large number of organizations working among product and service industries had realized the great importance of adopting and implementing TQM process in order to maintain a sustainable competitive advantage in a rapid changing environment. In addition, this research provides a better understanding of how different groups of frontline managers, chiefs, and employees perceive their readiness towards the business excellence culture and performance in the hotels. A questionnaire has been developed among representative sample of managers, executives, and lower-level employees in Red Sea area "Hurghada, El-Gouna, Makadi". Simple percentage, mean, T-test and ANOVA were used to test significant differences and data analysis; Comparison between the mean values of different groups was done using ANOVA with post hoc using Least Significant Difference (LSD) test Respondents display the main factors to quality culture practices and business excellence performance, help managers, decision makers, and practitioners TQM in better understanding of TQM critical success factors and to focus on the identified ones while implementing TQM in their hotels.
\end{abstract}

Keywords: Quality Culture; Performance Excellence; Hospitality Industry

\section{Introduction}

Healthy and long-term relationships with employees, customers, suppliers, and other social stakeholders are essential for success in hospitality organizations. Effective management of frontline employees' attitudes is pivotal for the perpetual improvement of business performance. This is also valid for tourism and hospitality organizations. Specifically, proper management of frontline employees' perceptions and behaviors is of the utmost importance in creating and enhancing quality, employee satisfaction, and performance as well as ensuring delighted and loyal customers and establishing well-rounded relations with suppliers and other social shareholders (Keng et al., 2007).

Business excellence is important in creating sustainable and continuous quality improvement of business processes that may bring strong financial performance, high customer demand, goal achievement, successful employee recruitment and admission, desired product and service outcome, and outstanding staff (Kanji, 2002), while some Excellence models are generic because they include all principles and concepts of total quality management (TQM), others are called 'in-house models' 


\section{Achieving the Performance Excellence through Quality Culture Improvement Strategy in Hospitality Industry}

(or special-purposed models) and are developed for TQM processes of specific organizations. Many studies in quality literature are conceptual, for example, Kanji's pyramid model (Kanji, 1996).

This research discusses business excellence settings in terms of quality culture performance and improvement and contributes to the literature in at least five ways. First, the in-house model provided in this study consists of Kanji's critical success factors, which, for the first time in quality literature on small- or medium-sized hotels, examined the perspective of three staff levels (top, middle, and lower level employees). There have been similar, but rare, studies on the quality culture perception or readiness factors in hotels, which is why existing quality award models are criticized for lack of any common agreement concerning their implementation (Arasli, 2002; Dahlgaard-Park and Dahlgaard, 2007). Additionally, there is no study (according to the author knowledge) consider the readiness for an excellence culture in a developing country such as Egypt. Second, there are very few studies on frontline employees within the hotel industry (Yoon et al., 2001). Third, there have been no studies on business excellence culture in Egypt.

According to Bowon et al., (2001); Hsieh et al., (2002) and Chi-Kuang et al., (2012), only a limited number of studies have specifically focused on business excellence culture and performance in the hotel industry. Recognizing these voids in quality and hospitality literature, the present study develops quality culture model for the hotels in Egypt that is based on Kanji's quality culture factors using data collected from frontline employees, supervisors, and managers in Red Sea hotels. The following section presents the theoretical background and research model. Afterward, respectively, the research methodology and results of the empirical study are discussed, and the study concludes with implications of the results and avenues for future research.

\section{Literature Review}

\section{Performance Excellence Models, Criticisms, and Supporters}

Achieving business excellence, maximizing social shareholders value, providing process excellence, improving organizational learning and delighting social shareholders are crucial elements for organizations, including hospitality and tourism organizations; (Endowsman and Savage-Moore, 1991). To determine leading factors that will create this culture to survive or growth in organizations and inject this culture into service organizations, an organization must begin on a well-grounded basis within organizations in developing countries. Specifically, without the incremental improvement strategy, one of the most vital elements of business excellence, the outcomes from daily improvement are unlikely to be sustainable. Finally, business excellence models offer guidelines to measure organizational performance and achieve excellence, in this respect; different business excellence models were prepared (Kanji, 2002).

As the need for quality management was identified in organizations, different models were developed. In turn, various quality awards were devoted to increase competitiveness in different parts of the world; the Deming Prize in Japan, developed in 1951, was one of the first. When Peters and Waterman (1984) published their famous book "In search of excellence - lessons from America's best-run companies", there have been many implications for a description of business excellence and for the success criteria behind excellence. Peters and Waterman examined whether managers got more done if they paid attention to the seven S's (structure, strategy, systems, shared values, skills, staff, and style), instead of just two (hardware criteria). They also examined whether real change in large institutions was a function of how management understands and handles the complexities of the 7-S model.

Business excellence models developed and many other criteria were added to excellence models; however, the common belief was that business excellence could create a sustainable competitive advantage. Kanji (2002) and Rusjan (2005) explained business excellence by stating that organizations are in need of a comprehensive, flexible, and effective structure. Success not only depends on an arrangement of holistic, highlighting, and interrelated factors but also on the impact 


\section{Achieving the Performance Excellence through Quality Culture Improvement Strategy in Hospitality Industry}

that any change in one of these components will have on the overall system. Breiter et al., (1995); Crosby (1996) criticized business excellence as giving the impression of containing the wisdom necessary to install quality management. He noted that, although the 1960s and 1970s were the golden days for quality assurance and acceptable quality levels were standard, nothing worked well. Deming argued that Malcolm Baldrige's National Quality Model (MBNQM) focuses on the results and avoids the important principles of TQM. Other authors also criticized EFQM, MBQA, and similar awardbased models; however, there is lack of consensus among practitioners as to how and where to start or continue with these excellence models during implementation. Further, some companies find them too complicated, time-consuming, and costly to put into practice. One basic reason behind their failure is that the criteria are perceived as a promotional tool rather than a quality improvement tool. Another reason is an existing management paradigm that determines the direction and focus of the model and neglects contextual realities (Curry and Kadasah, 2002; Dahlgaard-Park and Dahlgaard, 2007; Oakland and Tanner, 2008).

Cook and Verma (2002) indicated a significant positive relationship between business excellence and performance. Gronroos (2000) mentioned the growing interest and increased awareness and acceptance of the principles of business excellence in service and argued that services comprise a substantial amount of the gross national product as well as a significant proportion of total employment in many countries. A careful analysis of practices of the aforementioned models or awards revealed that most are prepared by viable organizations or implemented under the supervision of advisory companies; some even have government support in developed countries. As DahlgaardPark and Dahlgaard (2007) stated, these business excellence models are more useful to gain a competitive advantage and realize high performance compared to an award application or promotion. However, hotels are in urgent need of establishing simple, fast, effective, and low-cost models.

\section{Kanji's Quality Culture Model and its Critical Success Factors}

According to Kanji's pyramid model, all aspects of business excellence should be considered to achieve a higher level of business excellence. In this model, leadership is a 'prime' that shapes and controls the behavior of every principle and constitutes the core concept of the pyramid model. Kanji's business excellence model is a combination of Kanji's pyramid model and its expansion to a highly developed measurement system. In addition, this model aims to measure organizations' excellence by applying statistical concepts, which allows researchers to analyze the interactions between quality dimensions such as leadership, customer satisfaction, and employee satisfaction (Kanji, 2002).

Kanji's model in table 1 consists of a 'prime-leadership' with five principles that include delighting the customer, management by fact, people-based management, and continuous improvement. Kanji's easily adaptable model is not necessarily free; however, is less costly and time efficient compared to the other well-known models presented above. This model also applies a comprehensive statistical analysis and has a strong focus on improvement rather than positioning the organization's quality management scheme (Kanji, 2002). This study presents a simple, fast, and lowcost quality improvement model using Kanji's critical success factors as readiness factors. Much of the extant literature supports the need for strong quality culture leadership that promotes agreement and understanding between employees, supervisors, and managers for a successful quality culture initiative.

As seen in the literature, initial employee resistance and dysfunctional organizational culture which had been shown as one of the most important reasons for the destruction of many TQM efforts before they even begin (Arasli, 2002; Brah and Tee, 2002). There is a precondition with this model; staff may come to a common agreement with the support of top management to accept change, become committed, and perform company objectives. The recent total quality perspective recommends involvement from social shareholders (i.e. customers, suppliers' concerns) in the company's quality culture development and assessment. 
Achieving the Performance Excellence through Quality Culture Improvement Strategy in Hospitality Industry

Table (1): Critical business excellence success factors; based on Kanji's quality model.

\begin{tabular}{|c|c|}
\hline 1. Leadership & $\begin{array}{l}\text { Leadership defines quality culture as being related to the } \\
\text { vision, mission, and goals of the organization. Leadership aims } \\
\text { to establish shared values and launch systems to increase } \\
\text { customer satisfaction. Leadership also communicates, defines, } \\
\text { and motivates continuous improvement }\end{array}$ \\
\hline $\begin{array}{l}\text { 2. Delight the } \\
\text { customer }\end{array}$ & $\begin{array}{l}\text { An organization should establish objectives that increase } \\
\text { customer satisfaction according to the needs and expectations } \\
\text { of external and internal customers. Organizations should } \\
\text { supervise and predict changes in customer performance. } \\
\text { Moreover, as organization must listen to its customers and } \\
\text { verify their current and future expectations, they can use } \\
\text { feedback from customers to improve products and services, in } \\
\text { turn delighting the customer. This includes two core concepts: } \\
\text { External Customer Satisfaction and Internal Customer } \\
\text { Satisfaction }\end{array}$ \\
\hline $\begin{array}{l}\text { 3.External } \\
\text { customer } \\
\text { satisfaction }\end{array}$ & $\begin{array}{l}\text { External customer satisfaction shows the extent, to which the } \\
\text { organization handles criticisms, tries to resolve conflict, uses } \\
\text { information gained for quality improvement, and avoids the } \\
\text { reoccurrence of problems. It also measures the performance of } \\
\text { the organization in terms of meeting customer objectives. } \\
\text { Furthermore, external customer satisfaction compares } \\
\text { customer satisfaction results with those of other competitors }\end{array}$ \\
\hline $\begin{array}{l}\text { 4.Internal } \\
\text { customer } \\
\text { satisfaction }\end{array}$ & $\begin{array}{l}\text { Internal customer satisfaction shows the extent to which the } \\
\text { organization uses methods to increase coordination of co- } \\
\text { dependent tasks. Each employee must realize that the } \\
\text { organization has customers and suppliers and that there is } \\
\text { strong employee interaction between these entities }\end{array}$ \\
\hline $\begin{array}{l}\text { 5.Management } \\
\text { by fact }\end{array}$ & $\begin{array}{l}\text { Management by fact evaluates quality improvement } \\
\text { procedures using the organization's performance measurement } \\
\text { system. In addition, it distributes performance measurement } \\
\text { throughout the entire organization to improve its products and } \\
\text { processes }\end{array}$ \\
\hline $\begin{array}{l}6 \text { All work is } \\
\text { process }\end{array}$ & $\begin{array}{l}\text { The organization must follow a process-oriented method that } \\
\text { focuses on how the organization is working rather than the } \\
\text { results of the work. Quality requirements should be assessed } \\
\text { and this assessment should be used to enhance knowledge } \\
\text { about processes. Statistical methods are applied to control } \\
\text { processes }\end{array}$ \\
\hline 7.Measurement & $\begin{array}{l}\text { Processes are evaluated and causes of failure are determined } \\
\text { early. Furthermore, actions focus on changing processes. In } \\
\text { measurement, a wide range of precise performance indicators } \\
\text { are collected and an appropriate method is developed to assess } \\
\text { quality. Measurement helps the organization compare its past } \\
\text { and current performance with that of its competitors }\end{array}$ \\
\hline
\end{tabular}




\section{Achieving the Performance Excellence through Quality Culture Improvement Strategy in Hospitality Industry}

\begin{tabular}{|c|c|}
\hline $\begin{array}{l}\text { 8.People-based } \\
\text { management }\end{array}$ & $\begin{array}{l}\text { In people-based management, employees should feel that they } \\
\text { play an important role in the organization's success. Employee } \\
\text { contributions are valued by the organization. Feedback is } \\
\text { provided on employee performance, which is directly reflected } \\
\text { in the quality of the product or service provided by an } \\
\text { organization }\end{array}$ \\
\hline 9.Team work & $\begin{array}{l}\text { People in an organization should be provided with the } \\
\text { opportunity to work together as a team and should to be aware } \\
\text { of the importance of co-dependent tasks and enhanced } \\
\text { communication. Working in teams eases cross-functional } \\
\text { problems. Teams are platforms for change in an organization }\end{array}$ \\
\hline $\begin{array}{l}\text { 10. People make } \\
\text { quality }\end{array}$ & $\begin{array}{l}\text { Excellence is achieved through encouragement to produce } \\
\text { quality; therefore, excellence is not reached with standards, } \\
\text { systems, and technologies. People must be trained to improve } \\
\text { quality. Key factors to accomplish customer satisfaction } \\
\text { include involvement and commitment }\end{array}$ \\
\hline $\begin{array}{l}\text { 11.Continuous } \\
\text { improvement }\end{array}$ & $\begin{array}{l}\text { Continuous improvement observes change in customer orders. } \\
\text { The organization looks for ways to improve. Quality } \\
\text { improvement methods are used to improve all products, } \\
\text { services, and processes and the organization compares its } \\
\text { current quality levels of service with those of its competitors. }\end{array}$ \\
\hline $\begin{array}{l}\text { 12. Continuous } \\
\text { improvement } \\
\text { cycle }\end{array}$ & $\begin{array}{l}\text { Continuous improvement involves two core concepts: } \\
\text { continuous improvement cycle and prevention } \\
\text { Continuous improvement cycle recognizes small } \\
\text { developments and promotes a quality culture to satisfy internal } \\
\text { and external customers. }\end{array}$ \\
\hline 13. Prevention & $\begin{array}{l}\text { Costs of mistakes increase exponentially over time. The later } \\
\text { an action is taken to eradicate an error. The later on a mistake } \\
\text { is initiated, the more expensive it costs to correct that mistake. } \\
\text { An organization can increase its profit by preventing mistakes }\end{array}$ \\
\hline
\end{tabular}

Source :( Kanji, 2002)

As several authors have pointed out in the quality management literature (i.e. Weeks et al., 1995; Zairi, 2002; Dahlgaard, Pettersen, and Dahlgaard-Park, 2011) only very few studies have examined assessment criteria to measure TQM readiness prior to the development and implementation of business excellence culture. As Arasli, (2002) stated that "The organizational readiness process would inform the organization about the scope and the purpose of the quality initiative and help encourage support and participation". Therefore, with this model in table 2, it will be possible to shed light on the strengths and weaknesses of quality culture components as practiced by Egyptian hotel management from hotel staff perspectives. Further, this model will provide a database for hotels to measure their readiness towards a new approach and to compare practices and outcomes to make necessary improvements. 


\section{Achieving the Performance Excellence through Quality Culture Improvement Strategy in Hospitality Industry}

Table (2): TQM Critical Success Factors for service industry

\begin{tabular}{||l||l||}
\hline \hline 1- Leadership. & 2- Customer focus. \\
\hline 3- HRM practices. & 4- Quality improvement. \\
\hline 5- Continuous improvement. & 6- Teamwork. \\
\hline 7- Organizational culture. & 8- Service design. \\
\hline 9- Strategy and planning. & 10- Social responsibility. \\
\hline 11- Information and analysis. & 12- Training and education. \\
\hline 13- Union intervention. & 14- Employee empowerment. \\
\hline 15- Employee involvement. & 16- Employee satisfaction. \\
\hline 17- Rewards and recognition. & 18- Quality policy and technologies. \\
\hline 19- Communication. & 20- Supplier relationship management. \\
\hline 21- Process management. & 22- Benchmarking. \\
\hline
\end{tabular}

Adapted from: (Arasli, 2002)

There are reasons to develop and improve the Kanji's quality culture model: First, the results of extensive research on quality improvement models are used primarily by viable organizations in developing countries where in the service industry (hotels) receive little benefit owing to limited budgets and time compared to their larger counterparts. Second, the literature reveals a lack of knowledge about how to instill business excellence culture into the existing structures hotels, especially in developing countries (Wilkinson and Wilmott, 1994; Brah et al., 2000). Third, because frontline staff have boundary spanning functions, roles, and responsibilities in complex service settings, the three basic layers (e.g. managers, supervisors/ chiefs, and employees), relevant to their understanding and practices of business excellence culture, have been incorporated into the research model as a precondition for the transition to a business excellence culture system. However, no empirical study has evaluated the performance of the aforementioned quality culture characteristics using a sample of manager, supervisor, and frontline employees within the hotel industry simultaneously. Finally, there is a siren call for extensions of prior in-house quality improvement models in developing business excellence culture practices to motivate frontline employees to contribute to high organizational performance in developing countries (Wilson and Durant, 1994). Therefore, the results of this study will provide managers with useful practical guidelines within the hospitality industry.

\section{Research Methods}

Kanji defined business excellence as 'a means of measuring customers', employees' and shareholders' satisfaction simultaneously within an organization to obtain a comprehensive evaluation of the organization performance' (Kanji, 2002). Business excellence culture is the totality of the norms, beliefs, and values that control the behaviors of individuals and groups within an organization. Quality begins at the top of an organization and diffuses downward. This cultural transformation requires ownership and commitment from staff at different layers; otherwise; as has it happened in previous transitions to quality programs, staff would be a critical barrier and the transformation process would likely fail (Balbastre-Benavent and Canet-Giner, 2011). Therefore, business excellence readiness research provides an opportunity to design a roadmap to cover missing culture components or improve existing ones by taking necessary precautions on time and establishing organizational unity by helping staff adjust to change. Such information will allow organizations to see where they are, relevant to the excellence culture performance.

\section{Population and sampling}

The data in this study were obtained from three, four and five star hotels in Red Sea area "Hurghada, El-Gouna, Makadi". In each hotel, the department manager works under the direction of and reports directly to the general manager. Department chiefs largely serve the role of supervisors. The three, four, and five star hotels were selected because they attract the majority of tourists in Red Sea. A total 


\section{Achieving the Performance Excellence through Quality Culture Improvement Strategy in Hospitality Industry}

of 17 hotels ( 5 five-star, 7 four-star, and 5 three-star) were identified and included in this study. Stratified sampling was used to determine the total number of employees. The stratified sampling technique separates the population from relative homogeneous groups (Levin and Rubin, 1997). A questionnaire was distributed by the researcher. Among the 522 questionnaires distributed, 507 were collected in 3 weeks. The average return rates from the survey were $30.24 \%, 54.42 \%$, and $16.18 \%$, respectively, for managers, chiefs, and employees (see Table 3). Fifteen questionnaires were biased and, thus, excluded from the data evaluation process.

Table (3): Population and sampling distribution of total managers, chiefs, and employees

\begin{tabular}{||c||c||c||c||c||}
\hline Category & $\begin{array}{c}\text { Managers } \\
\text { sample/populat } \\
\text { ion }\end{array}$ & $\begin{array}{c}\text { Chiefs } \\
\text { sample/popul } \\
\text { ation }\end{array}$ & $\begin{array}{c}\text { Employees } \\
\text { sample/popul } \\
\text { ation }\end{array}$ & $\begin{array}{c}\text { Total } \\
\text { sample/populat } \\
\text { ion }\end{array}$ \\
\hline \hline Five star & $19 / 45$ & $21 / 48$ & $56 / 400$ & $96 / 493$ \\
hotels & $42.2 \%$ & $43.75 \%$ & $14 \%$ & $19.47 \%$ \\
\hline Four star & $24 / 55$ & $70 / 80$ & $140 / 770$ & $234 / 905$ \\
hotels & $43.63 \%$ & $87.5 \%$ & $18.18 \%$ & $25.85 \%$ \\
\hline Three star & $6 / 62$ & $32 / 98$ & $139 / 900$ & $177 / 1060$ \\
hotels & $9.67 \%$ & $32.65 \%$ & $15.44 \%$ & $16.69 \%$ \\
\hline Total & $49 / 162$ & $123 / 226$ & $335 / 2070$ & $507 / 2458$ \\
& $30.24 \%$ & $54.42 \%$ & $16.18 \%$ & $20.62 \%$ \\
\hline
\end{tabular}

\section{Survey Design}

Performance excellence culture items were activated via 59 items from Kanji, which tapped various aspects of business excellence quality culture. The items for leadership ( 6 items), delight the customer (11 items), management by fact (10 items), people-based management ( 9 items), and business excellence outcomes ( 7 items) were also drawn from Kanji (2002). The business excellence quality culture improvement survey was first prepared in English and translated into Arabic using back translation as advised by McGorry (2000). One English language translator participated in the preparation stage of the questionnaire. Translators were fluent in written and spoken English. A preliminary study with several respondents in hotels did not find any problems with the wording or format. Respondents were asked to indicate their degree of agreement with each system on a fivepoint Likert scale: 1, strongly disagree; 2 , agree; 3, somewhat agree/disagree; 4, agree; and 5, strongly agree. The measures were subjected to Cronabach alpha and Pearson product-moment correlation analyses through SPSS 15.0 to provide support internal consistency and discriminant validity, respectively.

\section{Data Analysis}

The collected data were transferred into SPSS to compute means, standard deviations, frequencies, and ANOVA. According to Levin and Rubin (1997), ANOVA tests are conducted to determine significant differences between more than two sample means. In an arithmetic average valuation unit, it is the average number of points, based on a five point Likert scale that people give to a certain statement. If any result is significant (0.05), there is a significant difference between perceptions of the groups; however, the reason for the difference will not necessarily be clear. Therefore, the related means must be considered and, if the average valuation for an instrument is above 4 or 5 , the indicator is positive (certainly agree or agree). If the average valuation by the respondents is around, equal, or less than 3, the indicator is negative (not agree or certainly not agree with the statement).

\section{Results and Discussion}

A one-way analysis of variance was used to determine whether there was a significant difference in perceptions among three different levels of staff. In general, the total means for the hotels staff showed 


\section{Achieving the Performance Excellence through Quality Culture Improvement Strategy in Hospitality Industry}

that managers expressed a moderate (between 4, agree and 3, neutral) score, while chiefs and employees reported $(<3)$ low levels of quality culture practices in their organizational settings. The results reveal that five star hotel staff shows significantly different scores $(P>0.05)$. Managers reported the highest scores; between agree (4) and neutral (3) on all items. Conversely, employees reported the lowest scores $(<3)$ on all items and chiefs had very close scores to those of the employees on the same items except continuous improvement. These low scores reveal the existing weaknesses of present quality culture practices within these organizations. These results also showed that five star hotel staff has significantly different scores among themselves. Overall, the total means for five star hotel staff demonstrates that (managers, 3.07; chiefs, 2.52; and employees, 2.36) all staff levels express a low level of business excellence outcomes.

The four star hotel staff also yielded significantly different scores. Managers reported the highest scores; mostly between certainly agree (5) and agree (4) on all items. On the other hand, employees had the lowest scores on most items and chiefs scored very close to employees on the same items except leadership, delight the customer, people-based management and continuous improvement. These results indicated that three star hotel staff had significantly different scores on seven outcome items. Overall, the total means for four star hotel staff indicated (managers, 3.29; chiefs, 2.42; and employees, 2.32) low levels of quality culture outcomes in their organizations. The three star hotel staff had significantly different scores except leadership items. The results also show that three star hotel staff had significantly different scores among themselves. Overall, the total means for three star hotel staff (managers, 2.83; chiefs, 2.53; and employees, 2.17) expressed a low level of quality culture outcomes.

The average factor mean scores revealed that five star hotel managers, chiefs, and employees yielded significant differences on perceptions of all performance excellence outcomes except from three dimensions: 'leadership', 'delight the customer', and 'external customer satisfaction' (see Table 4). When the total average mean scores of all dimensions were taken into consideration, all scores were between 2 and 3 (less than agree). Further, even managers did not yield an average aggregate mean score, including 13 Critical performance excellence factors, which was equal to 4 (agree This points to the fact that five star hotel staff perceive their business excellence practices as insufficient, ineffective, or unsuccessful. This finding exhibits the need for urgent implementation of strategies to instill a sense of ownership of the corporation's interests. Inevitably, employers will experience a high turnover, less productive systems, and poor service quality.

Table (4): Performance excellence critical factors survey five star hotel aggregate factor mean scores

\begin{tabular}{|c|c|c|c|c|c|c|}
\hline \multicolumn{2}{|c|}{$\begin{array}{l}\text { Performance excellence critical } \\
\text { factors }\end{array}$} & $\begin{array}{c}\text { Manag } \\
\text { er }\end{array}$ & Chief & $\begin{array}{c}\text { Employ } \\
\text { ee }\end{array}$ & $\begin{array}{c}\text { F- } \\
\text { statistic }\end{array}$ & Sign \\
\hline 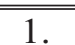 & "Leadership & 3.43 & 3.28 & 2.93 & 101.84 & 0.16 \\
\hline 2. & Delight the customer & 3.71 & 3.22 & 2.98 & 2.82 & 0.16 \\
\hline 3. & External customer & 3.62 & 3.07 & 2.92 & 3.01 & 0.05 \\
\hline 4. & Satisfaction & 3.73 & 3.03 & 2.96 & 4.37 & 0.01 \\
\hline 5. & Internal customer & 3.63 & 2.98 & 2.85 & 4.12 & 0.01 \\
\hline 6. & satisfaction & 3.76 & 3.13 & 2.83 & 5.21 & 0.00 \\
\hline 7. & Management by fact & 3.61 & 2.90 & 2.82 & 6.52 & 0.00 \\
\hline 8. & All work is process & 3.85 & 2.96 & 2.76 & 4.07 & 0.02 \\
\hline 9. & Measurement & 3.54 & 2.95 & 2.72 & 3.83 & 0.02 \\
\hline 10. & People based management & 3.68 & 3.05 & 2.86 & 3.84 & 0.02 \\
\hline 11. & Team work & 3.59 & 2.87 & 2.76 & 4.73 & 0.01 \\
\hline 12. & People make quality & 3.60 & 3.00 & 2.87 & 3.28 & 0.04 \\
\hline 13. & Continuous improvement & 3.63 & 3.07 & 2.83 & 3.70 & 0.02 \\
\hline
\end{tabular}


Achieving the Performance Excellence through Quality Culture Improvement Strategy in Hospitality Industry

\begin{tabular}{|l|l|l|l|l|l|l||}
\hline \hline $\begin{array}{l}\text { Continuous improvement } \\
\text { cycle } \\
\text { Prevention }\end{array}$ & & & & & \\
\hline
\end{tabular}

Note: Bold value denotes mean score is significantly different others; $\mathrm{P}<0.05$

When the average grand mean scores of four star hotel staff (managers, chiefs, and employees) were considered, they demonstrated significant differences in their perceptions in all performance excellence factors.

Table (5): Performance excellence critical factors survey four star hotels aggregate factor mean scores.

\begin{tabular}{|c|c|c|c|c|c|c|}
\hline \multicolumn{2}{|c|}{$\begin{array}{l}\text { Performance excellence critical } \\
\text { factors }\end{array}$} & $\begin{array}{c}\text { Manag } \\
\text { er }\end{array}$ & Chief & $\begin{array}{c}\text { Employ } \\
\text { ee }\end{array}$ & $\begin{array}{c}\text { F- } \\
\text { statistic }\end{array}$ & Sign \\
\hline 1. & Leadership & 4.15 & 2.85 & 2.85 & 33.35 & 0.00 \\
\hline 2. & Delight the customer & 4.22 & 2.97 & 3.00 & 24.43 & 0.00 \\
\hline 3. & External customer & 4.09 & 2.96 & 2.86 & 27.10 & 0.00 \\
\hline 4. & Satisfaction & 4.15 & 2.90 & 2.80 & 31.54 & 0.00 \\
\hline 5. & Internal customer & 3.98 & 2.95 & 2.84 & 19.51 & 0.00 \\
\hline 6. & satisfaction & 4.20 & 2.92 & 2.75 & 33.81 & 0.00 \\
\hline 7. & Management by fact & 3.90 & 2.91 & 2.80 & 29.92 & 0.00 \\
\hline 8. & All work is process & 4.19 & 2.86 & 2.82 & 21.86 & 0.00 \\
\hline 9. & Measurement & 4.16 & 2.86 & 2.72 & 33.86 & 0.00 \\
\hline 10. & People based management & 4.22 & 2.83 & 2.78 & 34.73 & 0.00 \\
\hline 11. & Team work & 3.98 & 2.83 & 2.84 & 22.60 & 0.00 \\
\hline 12. & People make quality & 4.12 & 2.92 & 2.81 & 27.92 & 0.00 \\
\hline 13. & $\begin{array}{l}\text { Continuous improvement } \\
\text { Continuous improvement } \\
\text { cycle } \\
\text { Prevention }\end{array}$ & 3.93 & 2.93 & 2.83 & 17.62 & 0.00 \\
\hline
\end{tabular}

Contrary to the three and five star hotel managers, four star hotel departmental managers indicated their effective quality practices regarding all 13 factors as evidences by mean scores that ranged from 3.90 to 4.22 (agree or close to certainly agree, see Table 5). In contrast to the managers, chiefs and employees agreed that their policies and implementations concerning business excellence factors had been unsuccessful.

In table 6, the average factors mean score reveals that three star hotel managers, chiefs, and employees, like their four star counterparts, yield significant differences in their perceptions of the performance of all business excellence practices. Specifically, employees gave their lowest scores (< 3 ) to every dimension. Chiefs provided a relatively better mean score than did employees; however, in general, scores were well below what was expected (less than four). This finding is indicative of a possible dissatisfaction with business excellence practices and outcomes in their hotels. The score also reveals the need for a complete overhaul. 
Achieving the Performance Excellence through Quality Culture Improvement Strategy in Hospitality Industry

Table (6): Performance excellence critical factors survey three star hotels aggregate factor mean scores.

\begin{tabular}{|c|c|c|c|c|c|c|}
\hline \multicolumn{2}{|c|}{$\begin{array}{l}\text { Performance excellence critical } \\
\text { factors }\end{array}$} & \multirow{2}{*}{$\begin{array}{c}\begin{array}{c}\text { Manag } \\
\text { er }\end{array} \\
3.58\end{array}$} & \multirow{2}{*}{$\begin{array}{l}\text { Chief } \\
2.89\end{array}$} & \multirow{2}{*}{ 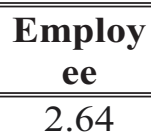 } & \multirow{2}{*}{$\begin{array}{c}\begin{array}{c}\text { F- } \\
\text { statistic }\end{array} \\
5.19\end{array}$} & \multirow{2}{*}{$\begin{array}{l}\text { Sign } \\
0.00\end{array}$} \\
\hline 1. & Leadership & & & & & \\
\hline 2. & Delight the customer & 3.66 & 3.05 & 2.67 & 6.59 & 0.00 \\
\hline 3. & External customer & 3.69 & 3.01 & 2.63 & 8.77 & 0.00 \\
\hline 4. & Satisfaction & 3.91 & 3.00 & 2.54 & 15.05 & 0.00 \\
\hline 5. & Internal customer & 3.77 & 3.05 & 2.56 & 12.70 & 0.00 \\
\hline 6. & satisfaction & 3.77 & 2.92 & 2.57 & 10.20 & 0.00 \\
\hline 7. & Management by fact & 3.83 & 2.96 & 2.52 & 13.36 & 0.00 \\
\hline 8. & All work is process & 3.83 & 2.95 & 2.53 & 14.11 & 0.00 \\
\hline 9. & Measurement & 3.77 & 2.90 & 2.48 & 11.44 & 0.00 \\
\hline 10. & People based management & 4.05 & 2.95 & 2.47 & 18.76 & 0.00 \\
\hline 11. & Team work & 3.72 & 3.03 & 2.55 & 12.36 & 0.00 \\
\hline 12. & People make quality & 3.83 & 3.06 & 2.53 & 15.02 & 0.00 \\
\hline 13. & $\begin{array}{l}\text { Continuous improvement } \\
\text { Continuous improvement } \\
\text { cycle } \\
\text { Prevention }\end{array}$ & 3.83 & 3.12 & 2.51 & 13.88 & 0.00 \\
\hline
\end{tabular}

\section{Conclusions, Implications and Recommendations}

This study aimed to diagnose strong and weak aspects of quality culture policies and practices from the perspective of three, four and five star hotels staff that hold manager, chief, and employee positions in Red Sea. Business excellence, in its simple sense, means doing things better and constantly improving staff, systems, processes, and organizations in a competitive environment. From this perspective, the main benefit of the present quality improvement model, which is based on Kanji's quality culture components, is that it is simple, fast, and low cost. The proposed model may also be applicable to all tourism, hospitality, and leisure sectors and may allow hotel administrations an opportunity to compare the perception of their staff to reveal strong or weak performance in their current quality practices and to determine how staff views such implementations. As a result, administrators will be able to take actions against discrepancies and failings, which could result in lack of direction, initiative, ownership, responsibility, contribution to organizational processes, or intention to quit or vice versa. Then, they can practice the same evaluation for customers, suppliers, and other social shareholders by preparing a suitable questionnaire, analyzing the data, and reporting results.

The interviews that were conducted with the top managers revealed a considerable number of the most common internal and external customer complaints in hotels business that should be effectively encounter through quality of service to achieve customers satisfaction, a great portion of these complaints are shown below:

External customer complaints:

1- Inadequate employee attire and attitude

2- Slow staff responsiveness to client's requests

3- Slow feedback to complains, (inaccurate or irrelevant corrective action may occur).

4- Billing problems (in accuracy, billing mistakes).

5- Overcharged services.

6- Staff appearance and tidiness is inappropriate.

7- Uninformative website.

8- Difficulties in booking online. 


\section{Achieving the Performance Excellence through Quality Culture Improvement Strategy in Hospitality Industry}

9- Insufficient staff experience and professionally.

10-Problems in hotel room maintenance.

11-Noisy activities close by the accommodation areas.

12-Booking, check in and checkout procedures are confusing.

Internal customers Complaints:

1- Unfair compensation system design.

2- There is a shortage in maintaining a good customer relationship programs.

3- Work standards are based on quantity with a less attention to quality.

4- The hotel information gathering and analysis system is not effective.

5- Inappropriate working conditions

6- Poor communication channels.

7- The management adopts the policy of hit and run.

8 - Recruiting is not taken seriously.

9- Unfair, unfriendly management treatment.

10- Unclear hiring contract clauses.

11 - Poor training and development programs.

12- Lack/ little on the job training.

13- Long-term relationship with key suppliers does not exist.

14- Team work philosophy is not well embedded in the organization culture.

15- Poor transportation facilities.

Conducting systematic business excellence surveys will also provide regular, consistent, and low-cost information. Hotels can use the collected data to assess business excellence performance during certain periods and pinpoint areas in which they are improving or need improvement. In addition, by making comparisons between the same star hotels, hotel chains can use this information to measure their different units. At a micro level, a single hotel can evaluate its own quality performance against the indicated factors. Thus, hotels can benefit from the suggested model in measuring quality performance through the provided internal assessment criteria.

The present study can help in understanding the awareness of TQM in Red Sea hotels, investigating the TQM implementation experiences in the hotels, identification of the key TQM critical success factors for effective TQM implementation in five star hotels business, Assessing the hotels performance with the adoption of TQM program, The proposed research model will allow practitioners and managers to assess the level of company's quality management against other models proposed by quality gurus, the model can also provide a baseline measure for the extent of TQM practices that is in place at a hotel. Thus, knowledge of this baseline can help in gaining continuous improvement in the hotel management performance and managers can further enhance their knowledge in driving the identified key TQM practices from the study and maximize the potential of the formal quality system.

Quality performance evaluations of the hotels in Egypt revealed that their quality practices and performances are far from the expected levels. To exist and develop in a competitive industry such as tourism, hotel organizations, by recruiting proper leadership, which is called 'prime', must bring business excellence quality improvement policies and practices to their properties. Primarily, hotels can achieve this by setting a quality culture related vision, mission, and goals, establishing shared values and launching goals and systems to increase customer satisfaction. The primeleadership should communicate, define, and motivate continuous improvement.

Second, hotels must go beyond internal and external customer needs and expectations by listening to customer suggestions and verifying their current and future needs and expectations. Moreover, organizations should handle complaints, try to resolve them, and use the information gained for their quality improvement; therefore, avoiding the recurrence of a problem. Hotel management should also work with 'management by fact' where they establish and evaluate their quality improvement processes using the organization's performance measurement system. Finally, 


\section{Achieving the Performance Excellence through Quality Culture Improvement Strategy in Hospitality Industry}

top management should use 'people-based management' where they support, lead, coach, and increase the efficiency of teamwork and give sufficient empowerment to enhance participation and provide better training and education to back up these improvement efforts.

Some limitations must be considered for future research. Although the survey results were derived from a single sector, hotels of Red sea area, which represent Egypt's hospitality industry, future research may collect data from other regions in Egypt. The results may generally be limited, although this study was the first aimed at developing a new and low-cost model based on Kanji's success factors for measuring excellence culture and performance in hotel organizations in Red Sea. To improve the model, additional studies that include suppliers and customers are needed. Such studies should also consider increased sample sizes, geographical diversity, and organization type. Second, the current findings are based on employee survey data, which may not be sufficient to examine total quality culture. Third, other major constructs that are related to the performance excellence implementation process, including degree of customer participation, degree of supplier, and level of community involvement, should be added to the conceptual framework that underlies this study. A longitudinal study may be used to ascertain how reliable the model is over a period of time. It is also proposed that future research be conducted in other types of organizations such as those in manufacturing and service using a similar approach.

\section{References}

Arasli, H. (2002). Diagnosing whether northern Cyprus hotels are ready for TQM: An empirical analysis. Total Quality Management, 13(3), pp.347-364.

Arasli, H. (2012). Towards business excellence in the hospitality industry: a case for 3-, 4-, and 5-star hotels in Iran. Total Quality Management and Business Excellence, 23 (5), pp. 573-590.

Balbastre-Benavent, F., and Canet-Giner, M.T. (2011). The strategy formation process in the EFQM excellence model: A critical review and new perspectives. Total Quality Management and Business Excellence, 22(7), pp.727-742.

Bowon, K., Jaisok, S., and Jongjoo, K. (2001). Managers' quality and performance perceptions: The case of the Korean semiconductor industry. Total Quality Management, 12(5), pp.643-655.

Brah, S.A. and Tee, S.S.L. 2002. Relationship between TQM and performance of Singapore companies. International Journal of Quality and Reliability Management, 19(4), pp. 356-379.

Brah, S. A., Wong, J. L. and Rao, B. M. 2000. TQM and business performance in the service sector: a Singapore study. International Journal of Operations and Production Management, 20(11), pp. 1293-1312.

Breiter,D, Tyink, S, A and Corey-Tuckwell, S, (1995), Bergstrom Hotels: a case study in quality, International Journal of Contemporary Hospitality Management, 7(6), pp.14-18.

Chi-Kuang.C, Sarasin.S and Jiun-Yi.J, (2012), Does Kanji's Business Excellence Model Work Well?A Study from the Measurement Aspect. Proceedings of the Asia Pacific Industrial Engineering and Management Systems Conference,pp. 991-1001.

Cook, L.S. and Verma, R. (2002), "Exploring the linkages between quality system, service quality, and performance excellence: service providers' perspectives", Quality Management Journal, 9(2), pp.44-56.

Crosby, P.B. (1996). Quality is still free. New York: McGraw-Hill.P.13

Curry, A. and Kadasah, N. 2002. Focusing on key elements of TQM-evaluation for sustainability. The TQM Magazine, 14 (4), pp. 207-216. 


\section{Achieving the Performance Excellence through Quality Culture Improvement Strategy in Hospitality Industry}

Dahlgaard, J.J., Pettersen, J., and Dahlgaard-Park, S.M. (2011). Quality and lean healthcare - A system for assessing and improving the health of healthcare organizations. Total Quality Management and Business Excellence, 22(6), pp.673-689.

Dahlgaard-Park, S.M., and Dahlgaard, J.J. (2007). Excellence - 25 years evolution. Journal of Management History, 13(4), pp.371-393.

Dahlgaard-Park, S.M., and Dahlgaard, J.J. (2010). Organizational learnability and innovability - A system for assessing, diagnosing and improving innovation excellence. International Journal of Quality and Service Sciences, 2(2), pp.153-174.

Endowsman, J.A., and Savage-Moore, W. (1991). Assess your organization's TQM posture and readiness to successfully compete for malcolm baldrige award. Industrial Engineering, 23(1), pp. $22-24$.

Gronroos, C. (2000). Service management and marketing: A customer relationship management approach (2nd ed.). Chicherster: Wiley.P.52, P64.

Hsieh, A.T., Chouand, C.-H., and Chen, C.-M. (2002). Job standardization and service quality: A closer look at the application of total quality management to the public sector. Total Quality Management, 13(7), pp899-912.

Kanji, G.K. (1996). Implementation and pitfalls of total quality management. Total Quality Management, 7, pp. 331-343.

Kanji, G.K. (2002). Measuring business excellence, advantages in management and business studies. London: Routledge.P.17,P.33.

Keng, B.O., Bakar, N.A., Arumugam, V., Vellapan, L., and Loke, A.K.Y. (2007). Does TQM influence employees' job satisfaction? An empirical case analysis. International Journal of Quality and Reliability Management, 24(1), pp.62-77.

Levin, R.I., and Rubin, D.S. (1997). Statistics for management. Upper Saddle River, NJ: Prentice Hall.P.23.

McGorry, P.D. (2000). Evaluating the importance of reducing the duration of untreated psychosis. Australian and New Zealand Journal of Psychiatry, 34, pp.5145-5149.

Oakland, J.S., and Tanner, S.J. (2008). The relationship between business excellence and performance - an empirical study using Kanji's leadership excellence model. Total Quality Management and

Business Excellence, 19, pp.733-749.

Peters, T.J., and Waterman, R.H. Jr., (1984). In search of excellence: Lessons from America's bestrun companies. New York: Harper and Row, Publishers. pp. xx, xxi-xxii, xxv.

Rusjan, B. (2005). Usefulness of the EFQM excellence model: Theoretical explanation of some conceptual and methodological issues. Total Quality Management and Business Excellence, 16(3), pp.363-380.

Weeks, B., Helms, M.M., and Ettkin, L.P. (1995). Is your organization ready for TQM? An assessment methodology. TQM Magazine, 7(5), pp.43-49.

Wilkinson, A., and Wilmott, H. (1994). Making quality critical: New perspectives on organizational change. London: Routledge.P.47.

Wilson, L.A., and Durant, R.F. (1994). Evaluating TQM: The case for a theory driven approach. Public Administration Review, 54(2),pp. 137-146. 


\section{Achieving the Performance Excellence through Quality Culture Improvement Strategy in Hospitality Industry}

Yoon, M.H., Beatty, S.E., and Suh, J. (2001). The effect of work climate on critical employee and customer outcomes: An employee level analysis. International Journal of Service Industry Management, 12(5), pp.500-521.

Zairi, M. (2002) Beyond TQM implementation: the new paradigm of TQM sustainability, Total Quality Management, 13(8), pp.1125-1140.

\section{تحقيق التميز فى الأداء من خلال استراتيجية ثقافة تحسين الجودة في صناعة الضيافة}

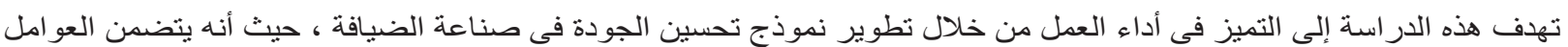

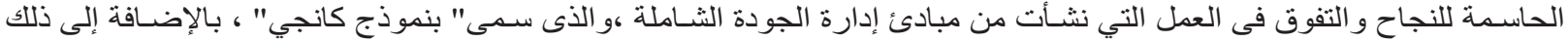

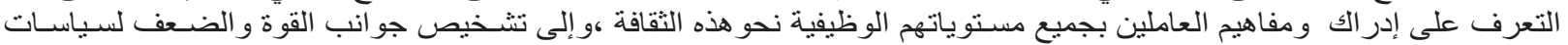

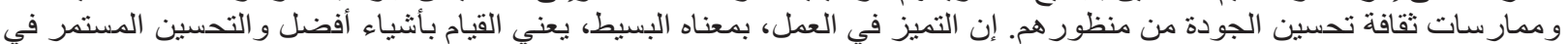

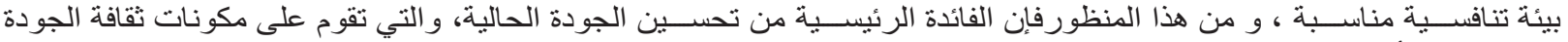

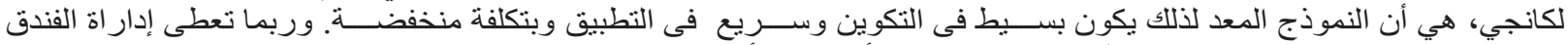

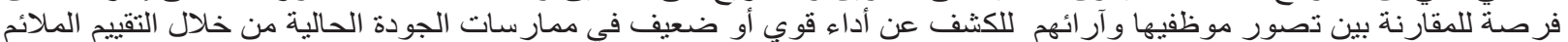

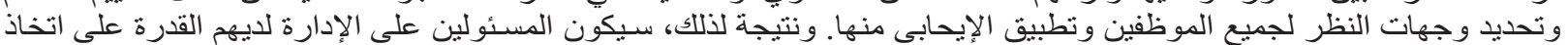

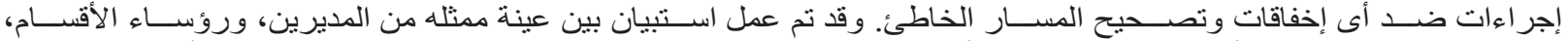

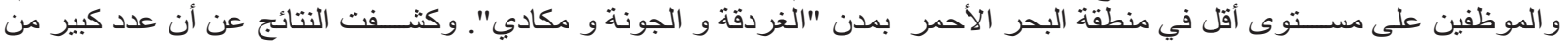

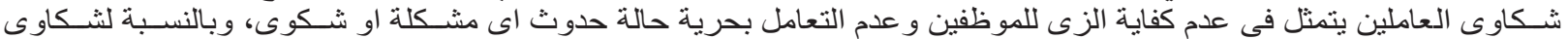

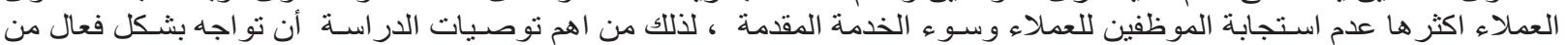

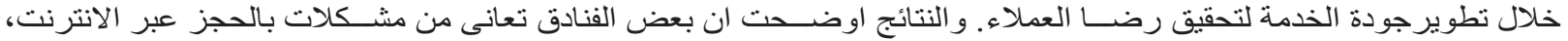

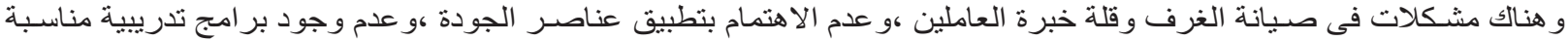

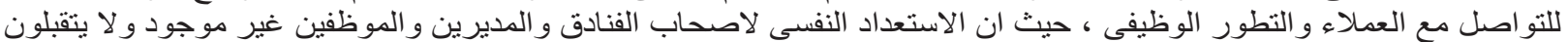

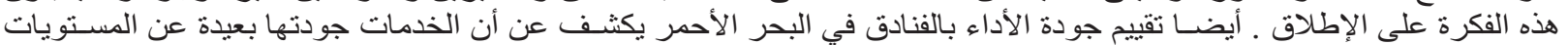

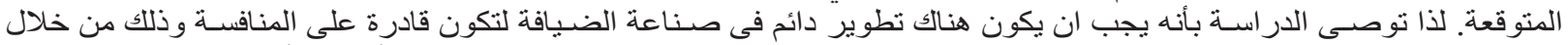

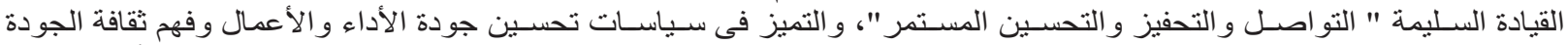

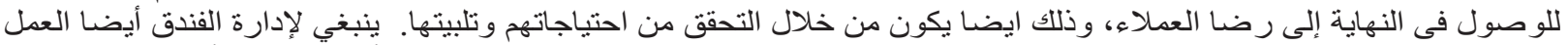

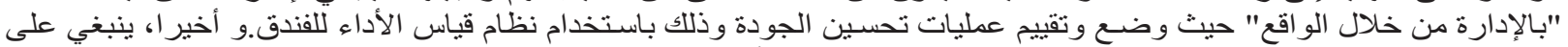

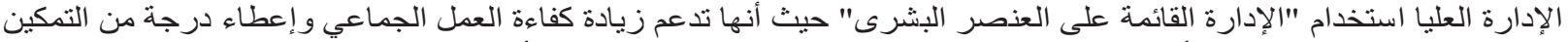

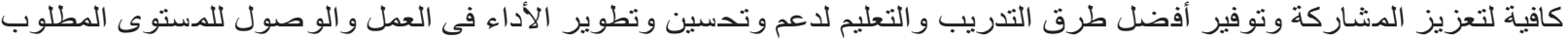

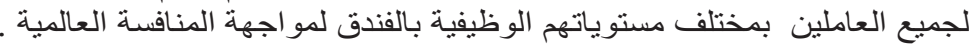

